\title{
Beyond Silence, Obstacle and Stigma: Revisiting the 'Problem' of Difference in Peacebuilding
}

\author{
Authors and affiliation: \\ Pol Bargués-Pedreny, Barcelona Centre for International Affairs \\ Xavier Mathieu, Aston University, x.mathieu@aston.ac.uk
}

\section{Acknowledgments:}

The authors wish to thank all the contributors to this Special Issue and the editors of the Journal of Intervention and Statebuilding for their enthusiasm for this project and their dedication to see it succeed. We are also grateful to the Centre for Global Cooperation Research (University of Duisburg-Essen) - and in particular Julia Fleck - for the financial and logistical help provided in organising the workshop that led to this Special Issue.

\begin{abstract}
Whereas practitioners and mainstream approaches to intervention are concerned about the inability to manage difference in a way that is conducive to peace, critical scholars worry about the inability to write difference without essentialising 'it' or reproducing and legitimising power structures. Can we revert the pessimism regarding the possibility to engage with others sensitively and build peace in a diverse world? In this article we argue that the current miasma of despair regarding international interventions is the result of three successive errors in the process of seeking to build a peace sensitive to the other: silencing, problematizing and stigmatising difference. After examining these three errors, we outline three analytical starting points that offer a better understanding of difference: multidimensionality, anti-essentialism, and a focus on power struggles. This discussion opens the Special Issue and hopes to stimulate further conversations on the role of difference in peacebuilding by focusing on its conditions of emergence.
\end{abstract}

\section{Introduction}

International peacebuilding as a practice and academic field has always been embroiled in the 'problem' of difference. To put it simply: how can peacebuilding be made to work in a diverse world? How do differences impact the process of peace? Since the late 1990s, sociocultural differences have been identified both as the origin of conflicts and as essential to build peace (Avruch 1998; Lederach 1997; Miall, Ramsbotham, and Woodhouse 1999). International organisations have gradually paid attention to the informal settings of societies 
intervened upon as spheres where differences are reproduced and the seeds of war and peace can be found. Even statebuilding frameworks, which tend to focus on the creation of legitimate governmental institutions and market reforms from 'the top-down', have become more willing to adjust to local contexts (Ingram 2010, OECD 2012). In the twenty-first century, it has become a platitude to admit that peace processes that are not led by local actors and respectful of their traditions and mores are doomed to go awry. Yet, among policymakers, there is a widespread pessimism about the possibility to engage with difference successfully so that a context-sensitive peace can be achieved. Sometimes cultural practices and societal codes seem difficult to comprehend to the external gaze, other times they seem incompatible with the aims of building peace.

In the scholarly literature, particularly within critical circles, the consensus is that international interventions have mostly failed because of the very superficial attention given to the needs, values and experience of the people in post-conflict societies (Kappler 2015, Mac Ginty and Firchow 2016, Richmond 2014). For universal liberal norms and international economic and security programmes cannot be transferred in a diverse world without costs and resistance from local traditions, identities and cultures. Critical reappraisals have thus argued for interventions that are respectful of local contexts and histories and connected with the 'everyday'. Yet the limits of this turn to the local have been widely recognised, as the tendency has been to reproduce Eurocentric lenses, dualisms and serve to legitimise unequal international relations (Chandler 2010; Lemay-Hébert and Mathieu 2014; Nadarajah and Rampton 2015; Randazzo 2016). As Meera Sabaratnam has it, even in critical frameworks of peacebuilding difference is often reduced to 'the liberal/ local distinction [that] appears to be the central ontological fulcrum upon which the rest of the political and ethical problems sit' (Sabaratnam 2017, 29, original emphasis). In sum, whereas practitioners and mainstream approaches worry about the inability to fully 'capture' difference or manage it in a way that is conducive to peace, critical scholars worry about the inability to 'write' difference without essentialising 'it' or reproducing and legitimising power structures. As difference seems fundamentally elusive, peacebuilding scholars and practitioners increasingly admit that the other cannot be helped and that any peace strategy that attempts to be sensitive to difference is doomed (Bargués-Pedreny 2017). Today critiques (and critiques of the critiques) burgeon while pessimism over peacebuilding spreads. Like the Titan Prometheus, who was punished by Zeus after he attempted to help humanity, practitioners or bold scholars who propose new solutions for peacebuilding are waiting for a critical eagle to eat their eternally regenerated liver.

Despite the centrality of the 'problem' of difference for the peacebuilding literature, the field is still lacking explicit theorisations of difference and comprehensive reviews on the way cognate disciplines have dealt with the concept of difference (for exceptions see Brigg 2008 and Behr 2014). In fact, difference seems to unite different strands of peacebuilding research yet its conceptualisation is mostly avoided. Throughout this Special Issue, we argue that a 
sustained attention to the theorisation, emergence and ambiguities of difference can shed light on some of the problems faced by peacebuilding. We propose to look at peacebuilding through the lens of difference to clarify and help solve some of the deadlocks faced by contemporary scholars and practitioners. As such, this Special Issue offers in-depth empirical and conceptual discussions of peacebuilding that do not shy away from discussing difference. The contributions assembled here seek to go beyond the stagnation and impasse that characterise the elusive engagement of the field with the 'problem' of difference. Nevertheless, neither this introduction nor the Special Issue seek to offer a 'successful' strategy to capture difference and redress peacebuilding. We rather pursue to act like the demigod Hercules who, more modestly, saved Prometheus from the eagle, rather than humanity.

In this introduction to the Special Issue, our objective is twofold. First, we argue that the miasma of despair regarding difference and peace is the result of three successive errors that occur when dealing with difference in international interventions: silencing, problematizing and stigmatising difference. The first error was common in early peacebuilding missions where difference was neglected altogether due to a belief in universalist ways of making peace and progress. Difference here had no relevance and no role to play. Later, statebuilding scholars and practitioners conceptualised difference as an obstacle to be assimilated, recognising for the first time that difference matters and needs to be considered due to its potentially negative impact on peace. Finally, current peacebuilding scholars and practitioners have become more tolerant of other worldviews but in their attempt to integrate difference they stigmatise it by overlooking the conditions of its emergence.

Secondly, after examining these three errors, we highlight the strategies used by the contributions assembled in this Special Issue and outline three analytical starting points that offer a better understanding of difference: multidimensionality, anti-essentialism, and a focus on power relations. First, differences are multidimensional and complex realities are performed differently in different peacebuilding settings, thus casting doubts on the existence of fixed characteristics of societies (and our ability to 'fix' them). Second, and following from the previous point, difference can be understood as vital to life yet as nonessential in nature. This leads to think peacebuilding as a relational process that cannot be brought to an end through deciding what difference is. Instead, rethinking difference as relational highlights the necessary postponement of conclusive settlements. Finally, and because societal and cultural differences reflect broader relations of power, the challenge for peacebuilding is not to include more differences (or more convincing and more 'micro' accounts of them) but to reveal the power relations that make differences exists in the first place. We develop these three alternatives by building upon the contributions to this Special Issue and connecting them to the relevant literature. 


\section{Avoiding Avruch's two errors: Undervaluing or Overvaluing Cultural Difference}

The work of Kevin Avruch is useful to frame the dilemma around difference that confronted peacebuilding analysts and policymakers throughout the 1990s and 2000s. As an anthropologist preoccupied with conflict resolution, Avruch (1998) criticised theories and practices of peacebuilding that rendered culture and cultural differences trivial. For him, 'undervaluing culture' is the 'first type of error' in traditional conflict resolution practices. These practices, he explained, tend to focus on rational negotiations between the representatives of disputing parties, as if context, values, traditions, or ethnic differences played no role for participants in a conflict. Initially, thus, Avruch could be read as pointing towards the championing of culture as an important element for understanding conflict and its resolution. However, Avruch does not suggest that we should talk about or emphasise culture unhesitatingly, with no holds barred, when addressing a cultural dispute. There is a 'second type of error' which surfaces in the process of trying to correct the first: the tendency to 'overvalue culture' by 'overestimating its impact on a conflict' (Avruch 2003, 363). Overemphasising culture is essentially harmful to some parties in a conflict already saturated with cultural animosities because, Avruch (2003, 367) contends, it homogenises, essentialises and reinforces particular forms of identity while neglecting or delegitimising others. In this introduction to the Special Issue, we first re-read the history of the field through Avruch's two errors and argue that throughout much of the 1990s peacebuilding scholars and practitioners erred because they generally undervalued culture whereas in the 2000 s the tendency was to recognise it but characterise it as an obstacle to peace. ${ }^{1}$

At the end of the Cold War, humanitarian questions attained universal scope and received unprecedented historical attention. In 1988, the UN Peacekeeping Forces received the Nobel Peace Prize for their missions in places such as Cyprus, the Democratic Republic of the Congo or the Middle East, reinvigorating the influence of the UN in international politics. In the following lustrum, the UN deployed twenty new peacekeeping operations more than in the previous four decades - and expanded the field roles to include complex and multidimensional tasks. The Secretary General, Boutros-Ghali (1992) strengthened the UN capacities to intervene internationally when adding the idea of 'post-conflict peacebuilding' to peace-prevention, peace-making and peace-keeping tasks. Based on the assumption that democracy and economic liberalism would facilitate war-peace transitions anywhere, the United States and other European states multiplied investment in democracy aid. They sponsored organisations facilitating free and fair elections, supervised legislative and judicial reforms and helped with the consolidation of independent media (Carothers 2000). And institutions such as the World Bank or the International Monetary Fund were leading global economic recovery through encouraging free-market structural adjustments in

\footnotetext{
${ }^{1}$ For heuristic reasons, this 'history' of peacebuilding is presented in a linear fashion. In reality, the 3 errors discussed here have co-existed and still do.
} 
impoverished regions (Williamson 1993).

In these early international peace support interventions, cultural differences were fairly neglected since every society was seen as willing and capable of democratising in a similar way (Doyle 1986; Fukuyama 1992; Huntington 1991). Differences among societies did certainly exist, but they represented the different stages of a universal and linear progression towards liberal democracy. Universal logics - such as actors interacting rationally in a perfectly calculable world - drove international relations, providing a convincing explanation for the deviations or delays of some local cultures (Lapid and Kratochwil 1996; Valbjørn 2008, 57-59). However, uncomfortable questions soared as peace proved difficult to consolidate in many non-Western countries throughout the 1990s. If democracy and free market were a source of peace and progress, why has some countries in transition to democracy failed to stabilize? Why had liberal multiculturalism been key to manage diversity and promote cultural rights to minorities in most Western states but failed as soon as it was exported elsewhere (Eller 1999; Kymlicka 2001)? Why was it so onerous to expand the liberal democratic zone of peace?

In debates assessing the difficulties of democratization, liberalization and peacebuilding in the aftermath of the civil wars in the non-West, the notion of difference appeared as a problem to be considered. The fact that democratisation and economic liberalisation were successful in the West, but failed to stabilise countries emerging from armed conflict in the non-West led to the perception that non-Western societies possessed specific traits that hindered their progress. Crucially, difference between human beings was expressed by referring to the inward and unconscious attributes of societies - their 'culture' or psychosocial specificities and logics - and it came to be a key explanatory variable for the failure of allegedly universal policy solutions (see, further, Furedi 1998; Malik 1996; Pupavac 2001). International interventions had thus been guilty of the first type of error identified by Avruch: they had ignored the relevance of culture and assumed that each society would transform into a peaceful liberal democracy in a similar way.

The focus on cultural differences thus revealed a feeling of growing disenchantment with universal values and approaches with worldwide pretensions. Scholars increasingly recognised not only that psychosocial factors had decisive effects on conflicts, but also that these could not be overlooked in peace processes (Avruch 1998; Avruch and Black 1991; Lederach 1997; Miall, Ramsbotham, and Woodhouse 1999). International interventions began to evolve from a concern with the formal and political sphere of societies to the regulation of the more informal settings where differences and inequalities among societies were reproduced over time (Chandler 2010). For example, at the end of the 1990s 'civil society' became a key component of programmes of international intervention (World Bank 2006). It was understood as an informal space beyond the state and formal rights, politics and economy, which had to be technically assisted and empowered in order to achieve 
tolerance and sustainable peace (for a critique, see Belloni 2001; Chandler 2006).

This emphasis on difference was considered a step forward when compared to earlier understandings that had assumed a one-size-fits-all peace model and ignored local histories, knowledge and mores. In moving from strictly military and security dimensions to targeting the broader social and cultural contexts of conflict-affected societies, these peacebuilding processes appeared apt to address the root causes of the problems and to facilitate psychosocial healing and long-term reconciliation (Lederach 1997, 24-35; Miall, Ramsbotham, and Woodhouse 1999, 206-15). Moreover, exhibiting cultural sensitivity in post-war scenarios was motivated by a normative commitment to respect diverse traditions at a time when Western countries were generally favouring multiculturalism, rather than assimilation, in domestic politics (Glazer 1997).

Nevertheless, a new problem appeared in peacebuilding processes when they gave primacy to culture: the emphasis on identities and differences ran the risk of legitimising belligerent ideas and reproducing frictions and divisions in societies affected by conflict. Often, particularly when deploying essentialist conceptions of identity and culture, which assume that groups are primordial, homogenous and clearly separated by their differences, frameworks of intervention were guilty of legitimising and replicating ethnonationalist perspectives and war-antagonisms (Campbell 1998, 88-93; Valbjørn 2008, 64; Vaughan-Williams 2006, 517-18). Thus a second type of error haunted peace interventions in the context of the 'cultural turn': as Avruch had warned, peace practitioners quickly realised that overvaluing culture brings as many problems as it solves.

Through much of the 2000s, internationally-led peacebuilding missions sought to find a solution to avoid the two errors: on the one hand, external actors could not ignore the primacy of those psychosocial factors that had influenced the history and development of the countries intervened in; on the other hand, they could not concede too much to local actors and cultures, and fuel the same identities and disagreements that had caused the turmoil. A tertium quid was required and took the form of a 'pragmatic tolerance' in which difference is valued insofar as it has a positive role for building peace. Thus peace missions adopted an unstable middle-ground position in which they would respect difference when seen as not obstructing the non-negotiable goals of stability, the rule of law and economic liberalism. Statebuilding frameworks, for example, can be said to be paradigmatic of a position that admitted the importance of culture in societies intervened in but considered it an obstacle that had to be managed, regulated and assimilated through a process of institution-building (Chesterman, Ignatieff, and Thakur 2005; Fukuyama 2005; Ghani and Lockhart 2008; Paris 2004). In the field of policy practice, the emphasis on strengthening institutions in places as diverse as Afghanistan, East-Timor, Iraq, Kosovo, or Sierra Leone was translated into a top-down strategy to transform the perceptions, beliefs and other socio-cultural pathologies of the people, so that they could learn to iron out their differences 
without resort to arms. The Weberian state became the fulcrum of peacebuilding processes, against which differences were censured if deviated too much from universal norms (LemayHébert and Mathieu, 2014). Even Avruch, who carried the torch of cultural sensitivity, became cautious not to include (and overvalue) some cultural traits when these hindered the goal of solving a conflict (for a critique, see Brigg and Muller 2009).

Statebuilding projects spread, but they did not win the day, as they ended up privileging the position of international agencies and foregrounding external values and models for peace resolution. While they recognised the importance of difference in processes of peacebuilding, they reduced most differences to obstacles to be managed, corrected and overcome so that the rule of law, state institutions and markets could be consolidated. In this sense, they reproduced what Antony Anghie (2005: 4) has called the 'dynamic of difference', that is, 'the endless process of creating a gap between two cultures, demarcating ones as 'universal' and civilized and the other as 'particular' and uncivilized, and seeking to bridge the gap by developing techniques to normalize the aberrant society'. If the first error had been to neglect those socio-cultural specific attributes that may affect the progress of peacebuilding processes, the second was to consider difference a barrier to the ends of external agencies.

\section{A Third Error: Stigma in the Critiques of Liberal Peace}

As liberal peace projects lost impetus (Campbell, Chandler, and Sabaratnam 2011), however, demands for approaches more sensitive to difference bourgeoned. Over the last ten years peacebuilding scholars have started to explain the poor record of international interventions by highlighting the insufficient or limited attempts at engaging more fully and genuinely with difference in processes of peacebuilding (Björkdahl and Gusic, 2015, Lidén, Mac Ginty et al., 2009, Mac Ginty, 2015, Mac Ginty and Richmond, 2016). This is self-evident in strategies to promote 'local ownership' which have frequently transferred power to the groups that seem to adjust to liberal norms but have disregarded other actors that are less donor-darlings (Lee and Özerdem, 2015). As a solution, scholars stress the need to engage more respectfully with 'the local', involving minorities as well as resistant, rural and other marginalised actors (Mac Ginty and Sylva Hamieh, 2010, Paffenholz, 2014). Next to academic debates, the policy field is slowly evolving, too. There is a growing awareness of the counter-productive effects of policies that are externally-imposed and prescriptive. Blueprints now include the necessity of including 'indigenous knowledge systems and practices' and the diverse resources existing locally in order to sustain peace (UNSSC 2010, 72-74; see also, UNDP 2016).

Critical approaches infer that peace needs to be fostered 'from below'; they are thus

necessarily more open to 'local-local actors', 'infrapolitical' dimensions and indigenous 'resistance' to foreign interventions (Richmond 2012, 116-127). Some studies propose as a 
sine qua non condition for consolidating peace the need to investigate at the micro level and develop more detailed and 'anthropological' analyses of local contexts (Richmond 2018, Schierenbeck, 2015). Others suggest developing positive forms of 'hybrid peace' in which 'international' and 'local' actors shape and participate in a localised process of peacebuilding (Mac Ginty and Richmond 2016, Wallis, Jeffery and Kent 2016; see further, Bargués-Pedreny and Randazzo 2018). In these cases, difference is not understood as 'culture', as culture is often related to reductionism and simplicity, but as the parapraxes, contingencies and twists that make the everyday life of a society unique.

Critical peacebuilding scholars have thus called for renewed attempts to engage with difference beyond the universalist assumptions characteristic of previous approaches. This implies a move beyond the second type of error outlined above: if difference was recognised, it was too quickly turned into a problem to be solved by assimilation. In contrast, critical scholars argue that difference has a role to play in building peace; whether this role is positive or negative depends on the circumstances and should not be judged a priori by external actors or measured against universal standards. These approaches therefore outline a third way to consider difference in the context of peacebuilding: beyond ignorance and problematisation (both leading to assimilation), difference is retrieved as indispensable for building peace.

This third way, however, brings in a new type of error that has long been noticed by scholars interested in the question of difference. Using the idea of a 'dilemma of difference' introduced by Minow (1990), the problem facing these recent peacebuilding approaches becomes clear. For Minow, when trying to correct the inequalities suffered by the different person, one can erase and ignore difference in an attempt to equalise actors (a 'solution' that tends to reproduce the hierarchy it was designed to erase) or, conversely, one can try to adapt to the characteristics of the different person. This second option, seemingly more tolerant and effective, necessitates the identification of what difference is. Yet as Minow argues difference never exists on its own: it becomes visible (and comes into being) only in relation to specific normative frames and expectations. As feminists have argued, for instance, women are only different insofar as the reference point is and remains men. The different person is identified by opposition to what/who is identical (and thus equal). As a consequence, any attempt at respecting and valuing difference necessitates its identification which in turn can only be achieved by reproducing the normative structures through which the different person was - and therefore remains - stigmatised.

Two consequences follow from this third error: differences are reified and essentialised as inescapable (for a critique, see Sabaratnam 2017, Nadarajah and Rampton 2015), but also, and perhaps more importantly, difference is linked to stigma (as a deviance from the 'normal' that is reproduced by the frames used to identify it). For instance, difference is often associated to 'informal institutions' or 'tradition'; yet these 'characteristics' only become 
salient through the use and acceptance of a specific normative frame influenced by Western perceptions of the 'normal'. In this frame, difference is identified in relation to what the Self believes bimself to be. As such, emphasising difference (even as something to be celebrated or as a space where bottom-up peace initiatives can be designed) does not remove the stigma attached to it insofar as what passes for 'normal' is not questioned nor made explicit.

Despite the fact that critical scholars strived to treat other societies on an equal footing (and refused to prejudge their values and mores in processes of peacebuilding), this third error makes the stated goal of integrating difference for peacebuilding counterproductive. In fact, the possibility of capturing difference 'on its own terms' has been largely acknowledged as unsuccessful or limited by critical scholars themselves. ${ }^{2}$ Recent research on peacebuilding has deplored this state of affairs (Sabaratnam 2017, Simons and Zanker 2014, Kappler 2015, Hirblinger and Simons 2015, Paffenholz 2015, and Randazzo 2016) but their conclusions seem to continue to give another life to the line of investigation that characterises critical peacebuilding. Indeed, they often urge - again - to be more sensitive to the particularities, specificities and intricacies of the 'different' societies intervened in. In doing so, they reproduce the logic of a critique that eats itself, first criticising previous approaches for failing to do justice to difference, and second trying it one more time, foreseeing that this new go will again be insufficient (Bargués-Pedreny 2017). Scholars (and practitioners) are gradually compelled to recognise their limited, temporal, political and thus biased view of difference, while any strategy to international peacebuilding becomes suspect.

In sum, these three errors constrain the capacity of peacebuilding practitioners and scholars to engage with difference on an equal footing. The first error meant the imposition of universalist frameworks by neglecting the particular identities and realities of the actors involved in peacebuilding. Difference was silenced as irrelevant due to the force of universalist convictions. Confronted with the failures of post-war interventions throughout the 1990s, external agencies began to consider the psychosocial spheres of societies intervened in, but only as something in need of correction, management and control (with the ultimate belief that assimilation to the universal model remained a viable strategy). These two errors reflect what Todorov (1982: 58) describes as the characteristic attitudes of the West towards difference: either the Other is assimilated to the Self and her difference goes unnoticed; or her difference is interpreted as inferiority and in need of transformation. The result is assimilation in both cases. Trying to move away from these two errors, current trends in peacebuilding research and practice have sought to reveal difference in its own terms and use it as a basis for building peace. Once again, however, these attempts are

\footnotetext{
${ }^{2}$ Recognitions of the limits of these academic attempts abound and are usually linked to the fact that the local Other cannot be identified as a fixed interlocutor - 'the local' has multiple, contingent and heterogeneous political identities which rely on perceptions and are thus dependent on the subjectivity of the scholar herself. See examples of these recognitions in Wanis-St. John (2013: 363), Mac Ginty (2015: 841-842), Björkdahl and Gusic (2015: 269), Mac Ginty and Firchow (2016), and for a more problem-solving approach recognising the ambiguities of the local see Schaefer (2010).
} 
limited by their refusal to engage with the conditions that make difference exist in the first place. Despite their generous starting points, the result is the reproduction of the stigma of difference.

Facing these dilemmas and contradictions, how is one to approach difference? The next section tentatively suggests how to move beyond the three common errors repeated in the theory and practice of peacebuilding. Instead of ignoring, problematizing, or asking for more detailed explorations of what difference $i$, we suggest focusing on three dimensions that have so far remained underexplored, idle lands in the field of peacebuilding. While we do not claim to introduce a new comprehensive peacebuilding framework, we maintain that focusing on these three dimensions can help solve some of the problems faced by peacebuilding scholars and practitioners by shedding new light on the issue of difference. In the remainder of this introduction, we propose three ways in which difference can be understood differently: as a multidimensional reality performed in multiple ways and contexts, as a vital yet non-essentialisable feature of human cultures, and as linked to power relations. We also explain how these conceptual arguments are used and furthered by the articles of this Special Issue.

\section{Thinking about Difference Differently in Peacebuilding}

\section{Performing (Multidimensional) Identities/Differences}

Against the desire to reduce differences to objective realities existing 'out there', the feminist and queer literatures offer a useful corrective (Butler 1990, 1993; Parker and Kosofksy Sedwick 1995). For these approaches, actors perform their identity through discourses and practices. This means that subjects are present and act but that there is no essential actor present before her (self-)enactment: subjects come into being (and enact their own differences) through the reiterated performance of their identity. Expressed differently, it means that the foundations to which discourses and practices of identification refer to in peacebuilding - 'traditions', 'modernity', 'history', 'indigeneity', local authenticity', 'international (scientific) expertise' - do not pre-exist their performance. This radical reconceptualisation of identity and difference changes the goals of those interested in peacebuilding: the objective is no longer to discover the 'real' identity of actors - in order to transform them or to adapt peacebuilding to their identity - but to understand how actors react to and enact regimes of identity (sometimes also exceeding them). Read's contribution (2018, this issue), for instance, explores how female aid workers struggle to perform the 'authentic' identity that the ideal of 'the field' and of 'humanitarian exceptionalism' require. These women express their feeling of only 'passing' as aid workers and their difficulty when faced with strict and alienating regimes of identity. As such, the capacity of these actors to identify to a dominant framework is ambiguous, rendering them seemly 'out of place'. 
Drawing attention to the performativity of difference also means recognising that differences are situated and depend on time and context. Actors can be 'local' in some situations - when they try to claim legitimacy through 'authenticity' - and 'international' in other contexts where legitimacy and resources derive from an attachment to a constructed position of 'exteriority' and thus 'objectivity' (Kappler, 2015). As shown by Martin de Almagro (2018, this issue), political movements and organisations involved in peacebuilding can perform their belonging to either sphere depending on their political motivations and the incentives of the context in which they act. What is important is to display the right type of difference at the right moment and place, taking into consideration that peacebuilding processes tend to favour certain subject positions, while constructing others as inappropriate (see, further, Martin de Almagro 2017). Similarly, as Hirblinger and Landau (2018, this issue) argue, difference is 'scaled' at the specific level of one group membership (thus disregarding the fact that individuals pertain to a variety of different groups). Peacebuilding can thus be read as the attempt to scale difference at the level thought to be most conducive to peace. This selectivity, of course, facilitates the construction of binary identities and 'entails the violence of repressing or ignoring other forms of difference’ (Abu-Lughod, 1991: 140).

In fact, recognising the performative aspect of differences also means that identities are inherently multidimensional - even if often reduced to one social category (ethnic, racial, religious, gender, class...) to the exclusion of other forms of identification. The political processes through which identities and differences are enacted act as a filter: while some characteristics are read as crucial, others are silenced. Recognising these forgotten dimensions could help us cultivate the points of connection and overlap that exist between supposedly different actors and to cross the boundaries between Self and Other in order to achieve peace:

Locating difference securely beyond the boundaries of self impedes our capacity to fully acknowledge and affirm others that always live within, or to appreciate and

claim selves that exist as part of others beyond those boundaries (Inayatullah and Blaney, 2004: 44).

The idea of multidimensionality is useful in that regard, yet such recognition can be difficult to achieve in a context where the act of othering helps people manage their fears about 'glimpses of dependence and "difference” in themselves' (Minow, 1990:378).

\section{Deferring closure, longing for relational and open-ended interactions}

Second, and in order to avoid the three types of errors that have preoccupied the field of peacebuilding in the past two decades, scholars can choose to insist on the irreducible character of identities, thereby refusing to represent them - let alone use them - in order to sustain peace. This position dwells on deconstructive sensitivities that highlight the 
irresolvable paradoxes implicated in attempts to make justice to difference: on one hand, there is a need for a decision or an action to assist the other; at the same time, any effort to do so will be unsatisfactory (Connolly 2002; Critchley 1992; Derrida 1992). The consequence of confronting these paradoxes is not stasis or utter impotence. Instead, deconstructive logics bring forward an unstable approach that affirms contradictory impulses while avoiding ultimate foundations. Vassilios Paipais (2011: 140) embraces this instability in order to solve the problem of assimilating difference and revitalise critique:

What is, perhaps, more important than seeking a final overcoming or dismissal of the self/other opposition is to gain the insight that it is the perpetual striving to preserve the tension and ambivalence between self and other that rescues both critique's authority and function.

If the task of solving tensions between identity and difference becomes impossible, it is a never-ending process that is privileged over closure and conclusions.

This is reminiscent of the argument made by David Campbell. Against dominant understandings of international intervention in Bosnia, Campbell $(1998,242)$ defends 'an ongoing political process of critique and invention that is never satisfied that a lasting solution can or has been reached'. This implies a double injunction of assisting indigenous needs, values and morals, while acknowledging the limits implicated in these tasks. Other authors have underlined the need for an engagement towards difference (and not with or of difference), holding an infinite predisposition to negotiate its constitution (Behr, 2014: 140). Taking this argument further, Behr (this issue) develops the concept of 'peace-in-difference' in which peace, as much as difference, is never defined of fixed but seen as a permanent process of dialogue which constantly neutralises essentialist categories and perceptions.

Yet this position is also interrogated in this Special Issue. For not all that is processual and contingent is positive, and that which is discrete and entrenched is negative. It may be that the apparent refusal to identify difference in the context of peacebuilding is not emancipatory, but instead reinforces or aligns with the powers that be. As Orjuela (2008: 248) explains, deconstructing identities is sometimes used as a weapon of domination if it serves to denounce as 'fake' or 'inauthentic' the identity of the marginalised. Moreover, some argue that deconstructive logics applied to identity are restricted to an academic and privileged position constructed above (identity) politics. Indeed, when faced with the necessity of making advances for peace, doing away with identities and differences rarely seems a viable option (as can be seen when choices and distinctions are made in the critical peacebuilding literature). ${ }^{3}$ Lottholz (2018, this issue) illustrates this point in the context of Kyrgyzstan where the attempts at forging a 'post-identitarian' peacebuilding have neither succeeded at transcending group differences nor at resolving conflict anxieties. Trying to 'solve' the problem of reifying differences by engaging in a never-ending process of blurring

\footnotetext{
${ }^{3}$ For a recent example of this problem see Visoka and Richmond (2017) and for a critique see Randazzo (2016).
} 
them provokes disorientation to practitioners and a deep frustration to local people claiming peace here and now.

A potential corrective to the limits of deconstruction in post-war settings could lie in a middle-ground as defined by Brigg (2008, 49 and 46): if identity and difference are 'fundamentally important', they should not be understood as implying 'strong boundaries among people' and we should remain 'circumspect about particular claims to have or know culture'. In her contribution to this Special Issue, Martin de Almagro (2018) develops this theme through the concept of 'hybrid clubs' in order to capture difference in a nonessentialist way: actors can perform their 'membership' to a variety of clubs without being essentially attached to them. Their difference is fluid and changing. Similarly, Brigg (2018, this issue) theorises difference as relational and essential at the same time. Indeed, difference is conceptualised as essential to life itself, unavoidable yet not essentialised in a 'substantialist' way. This is not to deny that difference can appear (and be presented) in essentialist terms by the actors themselves. Such a process can happen through 'strategic essentialism' (see for instance Krishna 1993; Inayatullah 2016) where actors naturalise their identities to serve specific purposes. Yet it remains for the scholar to adopt a sceptical perspective by showing how these differences remain politically constructed and reflecting on the worldview and social structures that made them salient in the first place.

\section{Difference as $A$ Relation of Power}

Finally, and building upon this last point, the ontological status of difference can be reconceptualised. Indeed, most peacebuilding research is built on the assumption that difference is empirically discoverable, identifiable and thus 'out there'. This common (mis)conception is shared by the three strands of peacebuilding examined earlier, which assume that difference can be identified in post-conflict societies or that difference is attached to the actors themselves. But as Maynard (2001, 310) writes, 'difference, as an organizing concept, tends to detract from our ability to consider the relationships between things and the possible consequences in terms of domination and control which ensue'.

As a response to this danger, scholars from a diversity of disciplines have shown how difference is a result of (power) relations. For instance, Minow discusses how differences lie between people and not within them. She argues that 'difference expresses patterns of relationships, social perceptions, and the design of institutions made by some without others in mind' (Minow 1990, 79), instead of essential and discrete characteristics of some people. Similarly, in anthropology, Abu-Lughod (1991: 147) explains that difference 'tends to be a relationship of power'. This means that differences are always the result of political and historical processes emerging from a particular economy of power (Escobar, 2008, 203): in each situation, and out of the almost infinity of traits that characterise s every actor, only 
some are portrayed as differences. All the contributions to this Special Issue deal with these themes by recognising that the difference of peacebuilding actors is always linked to broader relations of power. Read (2018, this issue), for example, explores how female aid workers mobilise their identity to confront the dominant masculine figure of the 'real' aid worker: here, gender comes to play an important role given the importance attributed to masculinity in humanitarianism.

Denying that difference emerges out of relations of power requires the belief that the Self is able to recognise difference and identity outside of culture and power altogether, to abstract herself from her own culture (Walley 1997). On the contrary, recognising the importance of power means that attention needs to be paid to the worldview(s) that powerful actors promote. As Brigg $(2008,11)$ points out, 'Much of what is at stake in the difference challenge relates, in other words, to different versions of truth and reality'. Only through these worldviews does difference emerge (usually as deviance or anomaly). Ignoring or silencing power - as was done in the universalist as well as in some of the recent stigmatising approaches - is no longer viable. Similarly, identifying differences as problems to be corrected becomes illogical insofar as these differences are created by those seeking to solve them. As Jonathan Joseph (2018) expresses in the final words of this issue, 'a relational approach to difference is more important than ever, but not without an analysis of the social and material relations that contribute to the production of difference'.

The recognition of difference as a relation of power linked to social structures that constrain and enable opens up new studies of thinking about difference and peacebuilding. In particular, the central questions are transformed: one no longer asks who is different and how this may be useful to build peace but rather how difference has been constructed by specific worldviews that are sustained by a particular economy of power. Bernath (2018, this issue), for instance, explores the construction of victim identities in Cambodia with reference to the powerful frame of 'genocide' and reveals how specific differences are entrenched in the process. The necessary yet problematic inscription of identities and differences can help solve conflict or reinforce it. More often than not, of course, this economy of power serves to sustain the order of the powerful Self (Behr 2014, 130). This means that identity and difference must be approached with caution as they legitimise some worldviews and social stratifications, whilst neglecting alternatives.

The three paths detailed here and explored by the contributions to this Special Issue represent an attempt to move beyond the three errors that characterise peacebuilding research and practice. By exploring difference conceptually and empirically, the authors provide concrete examples of a different way to approach difference in the context of peacebuilding. They deconstruct and interrogate the way differences come to exist in an attempt to transform current understandings of peacebuilding practices. They seek to open the way for further and more productive discussions on the role of difference in 
international interventions contexts. More broadly, this Special Issue participates in the discussion about equality in international relations and about the fundamental issue of our need to engage with others on an equal footing. This concern animates our work as scholars and is reflected in the contributions assembled here.

\section{References}

Abu-Lughod, L. (1991). "Writing against culture". Recapturing Anthropology: Working in the Present. R. G. Fox. Santa Fe, NM, School of American Research Press: 137-162.

Anghie, A. (2005). Imperialism, Sovereignty and the Making of International Law. Cambridge, Cambridge University Press.

Avruch, Kevin, and Peter W. Black. 1991. "The Culture Question and Conflict Resolution.” Peace \& Change 16 (1): 22-45. doi:10.1111/j.1468-0130.1991.tb00563.x.

Avruch, Kevin. 1998. "Culture and Conflict Resolution." Washington: US Institute of Peace Press.

Avruch, Kevin. 2003. "Type I and Type II Errors in Culturally Sensitive Conflict Resolution Practice." Conflict Resolution Quarterly 20 (3): 351-371. doi:10.1002/crq.29.

Bargués-Pedreny, P. (2017) "Connolly and the never-ending critiques of liberal peace: from the privilege of difference to vorarephilia." Cambridge Review of International Affairs 30 (2-3): 216-234.

Behr, H. (2014). Politics of Difference: Epistemologies of Peace. London and New York, Routledge.

Behr, H. (2018), "Peace-in-Difference: A phenomenological approach to peace through difference", Journal of Intervention and Statebuilding 12 (3):

Belloni, Roberto. 2001. "Civil Society and Peacebuilding in Bosnia and Herzegovina." Journal of Peace Research 38 (2): 163-180. doi:10.1177/0022343301038002003.

Bernath, J. (2018), "The Politics of Difference in Transitional Justice: Genocide and the Construction of Victimhood at the Khmer Rouge Tribunal", Journal of Intervention and Statebuilding 12 (3):

Björkdahl, A. and I. Gusic (2015). "'Global' norms and 'local' agency: frictional peacebuilding in Kosovo." Journal of International Relations and Development 18(3): 265-287.

Boutros-Ghali, Boutros. 1992. "An Agenda for Peace: Preventive Diplomacy, Peacemaking and Peace-Keeping.” International Relations 11 (3): 201-18. doi:10.1177/004711789201100302.

Brigg, M. (2008). The New Politics of Conflict Resolution Responding to Difference. Basingstoke, New York, Palgrave Macmillan.

Brigg, Morgan. 2010. "Culture: Challenges and Possibilities." In Palgrave Advances in Peacebuilding: Critical Developments and Approaches, edited by Oliver P Richmond, 329-346. London: Palgrave.

Brigg, M. (2018), "Relational and Essential: Theorizing Difference for Peacebuilding", Journal of Intervention and Statebuilding 12 (3):

Brigg, Morgan, and Kate Muller. 2009. "Conceptualising Culture in Conflict Resolution." Journal of Intercultural Studies 30 (2): 121-140. doi:10.1080/07256860902766784.

Butler, J. (1990). Gender Trouble: Feminism and the Subversion of Identity. New York - London, Routledge.

Butler, J. (1993). Bodies That Matter: On the Discursive Limits of "Sex". New York - London, Routledge.

Campbell, David. 1998. National Deconstruction: Violence, Identity, and Justice in Bosnia. Minneapolis: University of Minneapolis Press.

Campbell, S., D. Chandler, and M. Sabaratnam. 2011. A Liberal Peace? The Problems and Practices of Peacebuilding. London; New York: Zed Books.

Carothers, Thomas. 2000. "The Clinton Record on Democracy Promotion.” Working Papers 16. Washington, D.C.: Carnegie Endowment for International Peace.

Chandler, David. 2006. Constructing Global Civil Society: Morality and Power in International Relations. Basingstoke: Palgrave Macmillan. 
Chandler, David. 2010. "Culture and Civil Society: Peacebuilding Discourse and the Understanding of Difference.” Security Dialogue 41 (4): 369-90.

Chesterman, S., M. Ignatieff and R. Thakur (2005). Making States Work: State Failure and the Crisis of Governance. Tokyo, United Nations University Press.

Chesterman, Simon, Michael Ignatieff, and Ramesh Thakur. 2005. Making States Work: State Failure and the Crisis of Governance. Tokyo: United Nations Univeristy Press.

Connolly, William E. 2002. Identity/Difference: Democratic Negotiations of Political Paradox. Expanded ed. Minneapolis; London: University of Minnesota Press.

Derrida, Jacques. 1982. Margins of Philosophy. Brighton: The Harvester Press.

Doyle, Michael W. 1986. "Liberalism and World Politics." American Political Science Review 80 (4): 1151-1169.

Drichel, Simone. 2008. “The Time of Hybridity.” Philosophy \& Social Criticism 34 (6): 587-615.

Eller, Jack D. 1999. From Culture to Ethnicity to Conflict: An Anthropological Perspective on International Ethnic Conflict. Ann Arbor: University of Michigan Press.

Escobar, A. (2008). Territories of Difference: Place, Movements, Life, Redes. Durham and London, Duke University Press

Fukuyama, Francis. 1992. The End of History and the Last Man. New York: Free Press.

Fukuyama, Francis. 2005. State Building: Governance and World Order in the Twenty-First Century. London: Profile Books.

Furedi, Frank. 1998. The Silent War: Imperialism and the Changing Perception of Race. New Brunswick: Rutgers Univerity Press.

Ghani, Ashraf, and Clare Lockhart. 2008. Fixing Failed States: A Framework for Rebuilding a Fractured World. Oxford: Oxford University Press.

Glazer, Nathan. 1997. We Are All Multiculturalists Now. Harvard: Harvard University Press.

Hirblinger, A. T. and C. Simons (2015). "The good, the bad, and the powerful: Representations of the 'local' in peacebuilding." Security Dialogue 46(5): 422-439.

Hirblinger, A. and Dana M. Landau (2018), "Governing Conflict: The Politics of Scaling Difference", Journal of Intervention and Statebuilding 12 (3):

Huntington, Samuel P. 1991. “Democracy's Third Wave.” Journal of Democracy 2 (2): 12-34.

Inayatullah, N. (2016). "Gigging on the World Stage: Bossa Nova and Afrobeat after De-reification." Contexto Internacional 38(2): 523-543.

Inayatullah, N. and D. L. Blaney (2004). International Relations and the Problem of Difference. New York, Routledge.

Ingram, S. (2010) Statebuilding: Key Concepts and Operational Implications in Two Fragile States: The Case of Sierra Leone and Liberia. Washington, DC and New York, NY: The World Bank and UNDP.

Kappler, S. (2015). "The dynamic local: delocalisation and (re-)localisation in the search for peacebuilding identity." Third World Quarterly 36(5): 875-889.

Krishna, S. (1993). "Review: The Importance of Being Ironic: A Postcolonial View on Critical InternationalRelations Theory." Alternatives: Global, Local, Political 18(3): 385-417.

Kymlicka, Will. 2001. "Reply and Conclusion." In Can Liberal Pluralism Be Exported? Western Political Theory and Ethnic Relations in Eastern Europe, edited by Will Kymlicky and Magda Opalski, 345414. Oxford: Oxford Univerity Press.

Lapid, Yosef, and Friedrich Kratochwil. 1996. The Return of Culture and Identity in IR Theory. Boulder, CO; London: Lynne Rienner.

Lederach, John P. 1997. Building Peace: Sustainable Reconciliation in Divided Societies. Washington, D.C.: United States Institute of Peace Press.

Lee, S. Y. and A. Özerdem, Eds. (2015). Local Ownership in International Peacebuilding. London and New York, Routledge.

Lemay-Hébert, N. and X. Mathieu (2014). "The OECD's discourse on fragile states: expertise and the normalisation of knowledge production." Third World Quarterly 35(2): 232-251.

Lidén, K., R. Mac Ginty and O. P. Richmond (2009). "Introduction: Beyond Northern Epistemologies of Peace: Peacebuilding Reconstructed?" International Peacekeeping 16(5): 587-598. 
Lottholz, P. (2018), "Old slogans ringing hollow? The legacy of social engineering, statebuilding and the 'dilemma of difference' in (post-) Soviet Kyrgyzstan", Journal of Intervention and Statebuilding 12 (3):

Mac Ginty, R. (2015). "Where is the local? Critical localism and peacebuilding." Third World Quarterly 36(5): 840-856.

Mac Ginty, R. and C. Sylva Hamieh (2010). "Made in Lebanon: Local Participation and Indigenous Responses to Development and Post-war Reconstruction." Civil Wars 12(1-2): 47-64.

Mac Ginty, R. and O. P. Richmond (2016). "The fallacy of constructing hybrid political orders: a reappraisal of the hybrid turn in peacebuilding." International Peacekeeping 23(2): 219-239.

Mac Ginty, R. and P. Firchow (2016). "Top-down and bottom-up narratives of peace and conflict " Politics 36(3): 308-323

Malik, Kenan. 1996. The Meaning of Race: Race, History and Culture in Western Society. London: MacMillan.

Martin de Almagro, Maria. (2018), "Hybrid Clubs: A Feminist Approach to Peacebuilding in the Democratic Republic of Congo", Journal of Intervention and Statebuilding 12 (3):

Martin de Almagro, Maria. 2017. "Producing Participants: Gender, Race, Class, and Women, Peace and Security" Global Society https://doi.org/10.1080/13600826.2017.1380610.

Maynard, M. (2001). '"Race', Gender and the Concept of 'Difference' in Feminist Thought". Feminism: Critical Concepts in Literary and Cultural Studies. Volume 4: Feminism and the Politics of Difference. M. Evans. London and New York, Routledge: 300-316.

Miall, Hugh, Oliver Ramsbotham, and Tom Woodhouse. 1999. Contemporary Conflict Resolution: The Prevention, Management and Transformations of Deadly Conflicts. Malden, MA; Cambridge: Polity Press.

Minow, M. (1990). Making all the difference: Inclusion, exclusion, and America law. Ithaca, Cornell University Press.

Nadarajah, S. and D. Rampton (2015). "The limits of hybridity and the crisis of liberal peace." Review of International Studies 41(1): 49-72.

OECD (2012) International Support to Post-Conflict Transition: Rethinking Policy, Changing Practice. DAC Guidelines and Reference Series. Organisation for Economic Co-operation and Development (OECD) Publishing. http:// dx.doi.org/10.1787/9789264168336-en

Orjuela, C. (2008). The Identity Politics of Peacebuilding: Civil Society in War-torn Sri Lanka. New Delhi, Sage.

Paffenholz, T. (2014). "International peacebuilding goes local: analysing Lederach's conflict transformation theory and its ambivalent encounter with 20 years of practice." Peacebuilding 2(1): $11-27$.

Paffenholz, T. (2015). "Unpacking the local turn in peacebuilding: a critical assessment towards an agenda for future research." Third World Quarterly 36(5): 857-874.

Paipais, V. 2011. "Self and other in critical international theory: assimilation, incommensurability and the paradox of critique." Review of International Studies 37(1): 121-140.

Paris, R. and T. D. Sisk (2009). The Dilemmas of Statebuilding: Confronting the Contradictions of Postwar Peace Operations. London, Routledge.

Paris, Roland. 2004. At War's End: Building Peace after Civil Conflict. Cambridge: Cambridge University Press.

Parker, A. and E. K. Sedgwick (1995). "Introduction: Performativity and Performance". Performativity and Performance. A. Parker and E. K. Sedgwick. London, Routledge: 1-18.

Pupavac, Vanessa. 2001. "Therapeutic Governance: Psycho-Social Intervention and Trauma Risk Management.” Disasters 25 (4): 358-372. doi:10.1111/1467-7717.00184.

Randazzo, Elisa. 2016. "The paradoxes of the 'everyday': scrutinising the local turn in peace building." Third World Quarterly 37(8): 1351-1370.

Read, Roisin. (2018), "Embodying Difference: Reading Gender in Women's Memoirs of Humanitarianism", Journal of Intervention and Statebuilding 12 (3):

Richmond, Oliver P, and Roger Mac Ginty. 2015. "Where Now for the Critique of the Liberal Peace?" Cooperation and Conflict 50 (2): 171-89. 
Richmond, Oliver P. 2018. "Rescuing Peacebuilding? Anthropology and Peace Formation". Global Society 32 (2): 221-239.

Richmond, Oliver P. 2014. 'Jekyll or Hyde: What Is Statebuilding Creating? Evidence from the "Field", Cambridge Review of International Affairs 27 (1): 1-20.

Sabaratnam, M. (2017). Decolonizing Intervention: International Intervention in Mozambique (London and New York: Row man \& Littlefield).

Schaefer, Christoph Daniel. 2010. "Local Practices and Normative Frameworks in Peacebuilding." International Peacekeeping 17 (4):499-514

Schierenbeck, I. (2015). "Beyond the local turn divide: lessons learnt, relearnt and unlearnt." Third World Quarterly 36(5): 1023-1032.

Simons, C. and F. Zanker (2014). "Questioning the Local in Peacebuilding." Working paper of the Priority Programme 1448 of the German Research Foundation(10): Leipzig and Halle

Todorov, T. (1982). La conquête de l'Amérique. La question de l'autre. Paris, Editions du Seuil.

UNDP. 2016. "Local Governance in Fragile and Conflict Affected Settings: Building a Resilient Foundation for Peace and Development." A UNDP How-to Guide. New York: United Nations Development Programme.

UNSSC. 2010. Indigenous Peoples and Peacebuilding: A Compilation of Best Practices' Turin: United Nations System Staff College, Oficina de Promoció de la Pau i dels Drets Humans, Institut Català Internacional per la Pau.

Valbjørn, Morten. 2008. "Before, during and after the Cultural Turn: A 'Baedeker' to IR's Cultural Journey." International Review of Sociology 18 (1): 55-82.

Vaughan-Williams, Nick. 2006. "Towards a Problematisation of the Problematisations That Reduce Northern Ireland to a 'Problem." Critical Review of International Social and Political Philosophy 9 (4): 513-526. doi:10.1080/13698230600941978.

Visoka, G. and O. P. Richmond (2017). "After Liberal Peace? From Failed State-Building to an Emancipatory Peace in Kosovo." International Studies Perspectives 18(1): 110-129.

Walley, C. J. (1997). "Searching for "Voices": Feminism, Anthropology, and the Global D ebate over Female Genital Operations." Cultural Anthropology 12(3): 405-438.

Wallis, Joanne, Renee Jeffery, and Lia Kent. 2016. "Political Reconciliation in Timor Leste, Solomon Islands and Bougainville: The Dark Side of Hybridity. Australian Journal of International Affairs 70 (2): 159-178.

Wanis-St. John, Anthony 2013. "Indigenous Peacebuilding." In Routledge Handbook of Peacebuilding, edited by Roger Mac Ginty, 360-74. London: Routledge.

Williamson, John. 1993. Democracy and the "Washington Consensus." Vol. 21. doi:10.1016/0305750X(93)90046-C.

World Bank. 2006. Ciwil Society and Peacebuilding: Potential, Limitations and Critical Factors. Washington, D.C.: World Bank. 